Гуленникова T.P., доктор педагогічних наук, профбесор, директор Придунайської бьілї ПрАТ «ВНЗ «Міжрегіональна академія управління персоналом»

\author{
Метіль А. C., \\ кандидат юридичних наук, \\ старший викладач кафбедри української і всесвітньої історії та культури \\ Ізмаїльського державного гуманітарного університету
}

\title{
ХАРАКТЕРИСТИКА ДОМАШНЬОГО НАСИЛЬСТВА: ВІДПОВІДАЛЬНІСТЬ І НАСЛІДКИ
}

\begin{abstract}
Анотація. У роботі розглянуто загальні положення щодо здійснення сімейного насильства. Визначено його складові елементи. Надано загальну характеристику кожному елементу сімейного насильства. Визначено наявні й актуальні в майбутньому міри покарання за здійснення сімейного насильства, а також зазначено заходи, які спрямовані на запобігання домашньому насильству в будь-якій його формі.

Ключові слова: домашне (сімейне) насильство, психологічне насильство, фізичне насильство, економічне насильство, сексуальне насильство, сім'я.
\end{abstract}

Постановка проблеми. Згідно із ст. 3 Сімейного кодексу України, сім'я є первинним та основним осередком суспільства. Сім'ю утворюють особи, які спільно проживають, пов'язані спільним побутом, мають взаємні права та обов'язки [4].

В Україні проблема сімейного насильства стрімко набирає актуальності та потребує негайного втручання 3 боку соціальних працівників, психологів, правників тощо.

Сімейне життя називають однією із найбільш специфічних сфер відносин між людьми, яка найменше підлягає правовому регулюванню. Проте проблема насильства в сім'ї є головним порушенням прав людини, що вимагає її вирішення на державному рівні. Нормативною базою регулювання питань домашнього насильства $€$ Конституція України, Закон України «Про запобігання та протидію домашньому насильству», Кодекс України про адміністративні правопорушення, Кримінальний кодекс України, інші закони та міжнародно-правові договори, які ратифіковані в Україні.

Відповідно до Конституції України, життя людини визнано найвищим благом, права та свободи якої контролюються та захищаються відповідно до ч. 1 ст. 3: «Людина, ії життя і здоров'я, честь і гідність, недоторканність і безпека визнаються в Україні найвищою соціальною цінністю» [1].

Аналіз останніх досліджень і публікацій. Дослідженням питання домашнього насильства в сім'ї та розробленням засобів протидії йому займалися такі науковці та викладачі, як А.К. Виноградов, О.В. Бойко, О.М. Черевач, В.С. Бондар, ВВ. Голін, А.М. Ковальов, АК. Зайцев та інші.

Поняття «насильство в сім'ї» (домашнє насильство) - багатогранне. Відповідно до Закону України «Про запобігання та протидію домашньому насильству» насильство поділяється на такі складові елементи, як:

- фізичне насильство;
- психологічне насильство;

- сексуальне насильство;

- економічне насильство.

Закон України «Про запобігання та протидію домашньому насильству» трактує домашнє насильство як дію або бездіяльність фізичного, сексуального, психологічного або економічного насильства, вчиненого у родині або за місцем проживання, або між родичами, або між колишнім чи теперішнім подружжям, або між іншими особами, які спільно проживають однією сім'єю, але не перебувають у родинних відносинах чи у шлюбі між собою, незалежно від того, чи проживає особа, яка вчинила домашнє насильство, у тому самому місці, що й постраждала особа, а також погрози вчинення таких діянь[2].

Актуальність роботи зумовлена поширеністю проблеми сімейного насильства, збільшенням кількості сімей, що потерпають від насильства в сім'ї, а також наслідками, які воно завдає, та визначенням міри покарання для людей, які вчиняють домашне насильство.

Метою статті є дослідження та аналіз поняття «домашнє насильство», надання загальної характеристики всім різновидам домашнього насильства, визначення наслідків для осіб, що потерпають від насильства, а також характеристика міри покарання за вчинене насильство.

Завдання:

- охарактеризувати домашнє насильство;

- розглянути всі складники домашнього насильства;

- надати загальну характеристику наслідкам, які спричинені через потерпання від домашнього насильства;

- охарактеризувати міри покарання за здійснення домашнього насильства.

Виклад основного матеріалу дослідження. Проблема насильства в сім'ї дуже актуальна для українського суспільства, оскільки кількість сімей, які потерпають від нього, швидко зростає. Значна кількість людей і загалом сімей стоїть на обліку у правоохоронних органах за вчинення домашнього насильства. Причинами його здійснення варто вважати зловживання алкоголем чи наркотичними засобами, психічні розлади, соціальний та економічний стан, безробіття тощо.

Треба розглянути таких суб'єктів і жертв сімейного насильства, як чоловік або жінка, неповнолітні діти, престарілі родичі чи батьки, немічні родичі, усиновлювачі, а також усиновлені діти [5]. 
Необхідно розрізняти такі обов'язкові ознаки домашнього насильства, як:

- д діяння насильника повинне бути протиправним (суперечити нормам Конституції, Кодексу про адміністративні правопорушення, Кримінальному кодексу України та Закону України «Про запобігання та протидію домашньому насильству»);

- постраждалими від сімейного насильства можуть бути названі виключно члени сім'ї;

- діяння призвело чи могло призвести до порушення прав i свобод члена родини як людини та громадянина.

Є безліч класифікацій насильства, згідно з якими воно поділяється не тільки на загальновизнані форми - так звані фізичне, психологічне, сексуальне та економічне, але й за специфічними особливостями.

Залежно від часу дії насильство поділяють на таке, що було скоєне в минулому, й те, що скоєне в умовах сьогодення.

Залежно від стратегії кривдника насильство поділяють на явне та приховане.

Залежно від систематичності насильство в сім’ї поділяють на насильство одиничного прояву, систематичне та насильство, яке триває роками [7].

Однак, окрім зазначених вище форм сімейного насильства, виокремлюють також насильство на гендерній основі, відповідно до якого вчинення насильства однієї особи над іншою здійснюється на підставі статевих відмінностей.

Серед усіх форм домашнього насильства неможливо виокремити якусь одну, що є більш небезпечною для членів родини. А оскільки сімейне насильство - явище багатоаспектне, то треба охарактеризувати кожен складник окремо, виокремлюючи його особливості.

Під психологічним (емоційним) насильством розуміють форму домашнього насильства, яка передбачає погрози та словесні образи, залякування, приниження та інші діяння, які спрямовані на обмеження волевиявлення особи та контроль у репродуктивній сфері. Такі дії або бездіяльність можуть викликати в постраждалих осіб переживання за власну безпеку та спричинити емоційну невпевненість, нездатність самостійно захистити себе, що зрештою завдає шкоду психічному здоров'ю особи [2].

Під фізичним насильством розуміють форму домашнього насильства, що передбачає нанесення побоїв, тілесних ушкоджень різної тяжкості, незаконне позбавлення волі, мордування, залишення в небезпеці, ненадання допомоги особі, яка іiі потребує за станом здоров'я, заподіяння смерті, а також вчинення інших правопорушень насильницького характеру [7].

Сексуальне насильство трактують як вид домагання, який виражається у вчиненні діянь сексуального характеру, примусі до здійснення сексуальних дій проти волі жертви. До проявів сексуального насильства також варто віднести гнів на грунті ревнощів, приниження гідності лайливими словами та шляхом погроз примушувати жертву до сексуальних дій.

Також як окремий вид домашнього насильства виокремлюють економічне (фінансове) насильство, яке характеризують як форму домашнього насильства, яка передбачає умисне позбавлення житла, їжі, одягу та іншого майна, документів або коштів чи позбавлення можливості користування ними. А також залишення без піклування, перешкоджання в отриманні необхідних послуг із лікування чи реабілітації, заборона або, навпаки, примус до праці та інші правопорушення економічного характеру.
Варто зазначити, що досить рідко можливо натрапити на родину, у якій одночасно присутні всі складові елементи сімейного насильства. Однак часто трапляються сім'ї, в яких насильство проявляється одразу в декількох аспектах, а саме у психологічному та сексуальному, фізичному та сексуальному, економічному та фізичному аспектах тощо.

Виокремлюють три загальновідомі причини для здійснення домашнього насильства:

- як спосіб самоствердження;

- як відповідна реакція на насильство над собою;

- насильство заради порядку в родині [6].

Треба зазначити, що вчинення будь-якого виду домашнього насильства тягне за собою досить специфічні та непередбачувані наслідки, а саме:

- пошук схвалення своїх дій іншими людьми, особою, що зазнала вчинення домашнього насильства;

- почуття образи (внаслідок домашнього тиску особа відчуває образу як на кривдника, так і на самого себе, однак надалі почуття образи переростає та проявляється у вигляді роздратованості, почуття провини);

- доведення одного із членів родини до стану тривоги або в гіршому випадку - до депресії та психологічних розладів, які регулярно підлягають емоційному насиллю з боку родини;

- поява проблем у встановленні подальших відносин у суспільстві (зазнавши насильства в сім'ї, особа перестає довіряти оточенню загалом, через це відносини з іншими людьми неможливо встановити);

- здійснення особою самогубства внаслідок тривалого домашнього насильства.

Однак варто пам'ятати, що за вчинення особою насильства в сім'ї, незважаючи на його форму, окрім властивих йому наслідків, також настають психологічні наслідки, особливість яких залежить від форми насильства та його тривалості.

Щодо міри покарання, то треба зазначити, що відповідно до ст. 173-2 Кодексу України про адміністративні правопорушення вчинення домашнього насильства, насильства за ознакою статі, тобто умисне вчинення будь-яких діянь (дій або бездіяльності) фізичного, психологічного чи економічного характеру (застосування насильства, що не спричинило тілесних ушкоджень, погрози, образи чи переслідування, позбавлення житла, іжі, одягу, іншого майна або коштів, на які потерпілий має передбачене законом право, тощо), внаслідок чого могла бути чи була завдана шкода фізичному або психічному здоров'ю потерпілого, карається штрафом від 10 до 20 неоподатковуваних мінімумів доходів громадян або залученням до громадських робіт на строк від 30 до 40 годин, або адміністративним арештом на строк до 7 діб. За повторне вчинення дій особою, яку було піддано адміністративному стягненню, накладається таке покарання: штраф від 20 до 40 неоподатковуваних мінімумів доходів громадян або громадські роботи терміном від 40 до 60 годин, або адміністративний арешт на термін до 15 діб.

Кримінальний кодекс України, у свою чергу, не містить спеціальних норм, що передбачали б відповідальність за вчинення домашнього насильства, однак містить низку розділів, які передбачають покарання за діяння особи, що вчинила правопорушення на сімейно-побутовому рівні [8].

Однак, окрім загальновідомих, вищезазначених мір покарання за здійснення домашнього насильства, треба звернути увагу на інформацію офіційного вісника «Голос України», 
в якому опублікували Закон «Про запровадження кримінальної відповідальності за домашне насильство». Відповідно до цього Закону покарання за скоєння домашнього насильства стає більш посиленим. А саме: за вчинення насильства настає покарання у вигляді залучення до громадських робіт на термін від 150 до 240 годин або арешт до півроку, або обмеження волі до 5 років чи позбавлення волі до 2 років.

Кожний конкретний варіант насильства $€$ самостійною проблемою, що має притаманні ій специфічні риси. Задля запобігання домашньому насильству варто звертати увагу на притаманні саме йому причини, умови, форми прояву тощо.

Висновки. Підбиваючи підсумки та аналізуючи все вищевикладене, можна зазначити, що насильством у сім'ї називають діяння (дію або бездіяльність) фізичного, сексуального, економічного або психологічного насильства, що вчиняється в сім'ї.

Складну систему домашнього насильства неможливо уявити без іiі складових частин, а саме: економічного, психологічного, фізичного та сексуального елементів. Кожен складник цієї системи здатен спричиняти особливі, специфічні наслідки, які непередбачувано впливають на людину та іiї подальше життя.

За скоєння домашнього насильства незалежно від його виду настає відповідальність - чи то адміністративна, чи то кримінальна. Однак $з$ огляду на стрімке поширення проблеми домашнього насильства та збільшення сімей, які від нього потерпають, міри покарання за його здійснення у найближчому майбутньому планують посилити.

Наприклад, в умовах сьогодення за вчинення домашнього насильства в кожній із зазначених форм за законодавством України передбачено адміністративну відповідальність, яка може виражатися у вигляді штрафу, виправних робіт або адміністративного арешту.

Однак у найближчому майбутньому міри покарання за здійснення домашнього насильства планують посилити. Це проявляється у збільшенні терміну виправних робіт, позбавленні волі або арешті на певний строк.

Задля запобігання домашньому насильству сім’'і, які потребують допомоги, повинні звертатися за допомогою до психологів і соціальних робітників, а сім'ї, в яких насильство більше нагадує стабільність, повинні ставати на облік до належних державних органів. Також для поліпшення стану родин, що страждають від сімейного насильства, треба впроваджувати заходи, які будуть запобігати домашньому насильству та які запропоновані в Законі України «Про запобігання та протидію домашньому насильству».

До них можна зарахувати такі:

- організацію та проведення галузевих і міжгалузевих досліджень стану, причин і передумов поширення домашнього насильства;
- організацію та проведення серед населення інформаційних кампаній щодо запобігання та протидії домашньому насильству;

- залучення засобів масової інформації до проведення просвітницьких кампаній, спрямованих на виконання завдань у сфері запобігання домашньому насильству;

- організацію та проведення спільних і спеціалізованих тренінгів та семінарів.

\section{Jimepamypa:}

1. Конституція України: прийнята на п'ятій сесії Верховної Ради України 28 червня 1996 р. Відомості Верховної Ради України. 1996. № 30. Ст. 141.

2. Про запобігання та протидію домашньому насильству: Закон України від 7 грудня 2017 р. № 2229-VIII. Відомості Верховної Ради України. 2018. № 5. Ст. 35.

3. Кодекс України про адміністративні правопорушення від 7 грудня 1984 р. Відомості Верховної Ради Української РСР. 1984. Додаток до № 51. Ст. 1122.

4. Сімейний кодекс України від 10 січня 2002 р. Відомості Верховної Ради. 2002. № 21-22. Ст. 135.

5. Виноградов А.К. Поняття та види насильства в сім'ї в Україні. Південноукраїнський правничий часопис. 2016. №. 1. С. 50-53.

6. Черевач О.М. Адміністративно-правова характеристика насильства в сім’ї. Право і суспільство. 2011. №. 6. С. 147-151.

7. Мірошниченко О.В., Міхайліна Т.В. Насильство в сім'ї: Соціально-правова сутність та засоби протидії. Вісник. 2016. С. 42.

8. Качинська М.О. Окремі аспекти правового регулювання попередження насильства в сім'ї. Журнал східноєвропейського права. 2017. № 41. C. $37-43$.

Гуменникова Т. Р., Метиль А. С. Характеристика домашнего насилия: ответственность и последствия

Аннотация. В работе рассмотрены общие положения относительно осуществления семейного насилия. Определены его составляющие элементы. Предоставлена общая характеристика каждого элемента семейного насилия. Определены существующие и актуальные в будущем меры наказания за совершение семейного насилия, а также указаны мероприятия, направленные на предотвращение домашнего насилия в любой его форме.

Ключевые слова: домашнее (семейное) насилие, психологическое насилие, физическое насилие, экономическое насилие, сексуальное насилие, семья.

Gumennikova T., Metill A. Characteristics of domestic violence: responsibility and consequences

Summary. In the work reviewed the general provisions on the implementation of family violence. Its constituent elements are defined. The general characteristic of each element of domestic violence is given. The existing and actual in the future measures of punishment for committing family violence are identified, and also, there are measures aimed at preventing domestic violence in any form.

Key words: family violence, psychological violence, physical violence, economic violence, sexual violence, family. 